\title{
ARTICLE \\ Emerging platforms to monitor the occurrence and threats to critically endangered seabirds: The waved albatross in Chile and the Southeast Pacific
}

Plataformas emergentes para monitorear la ocurrencia y amenazas de aves marinas críticamente en peligro: El albatros de Galápagos en Chile y en el Pacífico Sudeste

\section{Cristián G. Suazo ${ }^{1,2 *}$, Oliver Yates ${ }^{3}$, Jorge Azócar ${ }^{4}$, Pablo Díaz Juan C. González-But ${ }^{2,6}$ and Luis A. Cabezas ${ }^{5,2}$}

\author{
'Department of Animal Ecology and Systematics, Justus Liebig University Giessen, Heinrich-Buff-Ring 38, 35392 Giessen, Germany \\ ${ }^{2}$ Albatross Task Force, BirdLife International, Chile. *Corresponding author: biosuazo@gmail.com \\ ${ }^{3}$ BirdLife International Marine Programme, RSPB, The Lodge, Sandy, Bedfordshire SG19 2DL, England, UK \\ ${ }^{4}$ Departamento de Evaluación de Pesquerías, División de Investigación Pesquera, Instituto de Fomento Pesquero (IFOP), Almirante \\ Manuel Blanco Encalada 839, Valparaíso, Chile \\ ${ }^{5}$ Facultad de Ciencias del Mar y de Recursos Naturales, Universidad de Valparaíso, Casilla 5080, Reñaca, Viña del Mar, Chile \\ ${ }^{6}$ Current address: Centro de Conservación Marina, Estación Costera de Investigaciones Marinas (ECIM), Pontificia Universidad \\ Católica de Chile, Osvaldo Marín 1672, Las Cruces, Chile
}

Resumen.- Las especies de aves marinas longevas, tales como albatros y petreles ampliamente distribuidos en el mar y con poblaciones reducidas, tienen a la captura incidental en pesquerías como una de las principales amenazas para su conservación. Entre estas, el albatros de Galápagos Phoebastria irrorata es escasamente detectado en las Zonas Económicas Exclusivas (ZEE) de países más allá de su distribución tradicional a lo largo del Pacífico Sudeste. En este artículo se recopilan registros distribucionales del albatros de Galápagos in situ y obtenidos desde observaciones no sistemáticas en el mar, tales como actividades de turismo (i.e., observación pelágica de aves) desde la década de 1980s en adelante. A su vez, se incorporan registros desde monitoreos sistemáticos en pesquerías de palangre y arrastre, operando entre el norte y centro-sur de Chile (Pacífico Sudeste). La ocurrencia de avistamientos fue analizada según características ambientales relacionadas a estos, como presencia/ausencia de periodo reproductivo e indicadores de eventos EI Niño, tal como valores negativos en el Índice de Oscilación Sur (IOS), entre otros. Se describió un total de 13 avistamientos del albatros de Galápagos y con $76,9 \%$ de estos fuera de su periodo reproductivo (diciembre a abril). Los registros evidencian una distribución meridional del albatros de Galápagos hasta el centro-sur de Chile $\left(38^{\circ} \mathrm{S}\right)$, alcanzando $4.391 \mathrm{~km}$ al sur de Islas Galápagos, así como hasta $920 \mathrm{~km}$ al oeste $\left(79^{\circ} \mathrm{O}\right)$ desde la costa Sudamericana. El albatros de Galápagos fue registrado en asociación con pesquerías industriales de palangre pelágico y arrastre demersal. No hubo registros de captura incidental, aunque la observación de individuos asociados a barcos de estas pesquerías para alimentarse de descartes y eviscerados sugiere un potencial riesgo de mortalidad para esta especie. El 53,8\% de los avistamientos fueron durante lecturas positivas del Índice de Oscilación Sur (IOS), representando condiciones más frías que las neutrales de El Niño Oscilación Sur (ENOS).

Palabras clave: Ciencia ciudadana, pesquerías, Sistema de Corriente de Humboldt, turismo

\begin{abstract}
Long-lived seabird species such as albatrosses and petrels, which are widely distributed at sea and have small populations are threatened globally by bycatch in fisheries. Among these, the waved albatross Phoebastria irrorata is scarcely detected in the Exclusive Economic Zones (EEZs) of countries beyond its traditional distribution throughout the Southeast Pacific. In this article, in situ distributional records on the waved albatross obtained from non-systematic (pelagic birdwatching) and systematic (fishery monitoring) records were compiled. Occurrence of sightings was carried out in relation to recording traits as presence/absence of breeding period and El Niño proxies such as the Southern Oscillation Index (SOI), among others. A total of 13 sightings of waved albatrosses was described which $76.9 \%$ of sightings were related to non-breeding period (December to April). Records indicated waved albatrosses reached $4,391 \mathrm{~km}$ south of the Galapagos Islands $\left(38^{\circ} \mathrm{S}\right)$ and $920 \mathrm{~km}$ west of the South American coast $\left(79^{\circ} \mathrm{W}\right)$. The waved albatross was associated with industrial pelagic longline and demersal trawl fisheries, and although there were no records of bycatch, the observation of individuals feeding on discards and offal suggests a potential risk of mortality for this species. $53.8 \%$ of sightings were during positive readings of the Southern Oscillation Index (SOI), representing colder conditions than neutral El Niño Southern Oscillation (ENSO).
\end{abstract}

Key words: Citizen science, tourism, fisheries, Humboldt Current System 


\section{INTRODUCTION}

Identifying the global distribution of marine vertebrates and threats pose to them facilitates the assessments of conservation status. Thus, studies of distribution patterns and geographic occurrence are key aspects in understanding relative threats to marine vertebrates in fishing operations (Robertson et al. 2014, 2017) as baselines to assess the effect of changes in management or practices on population status.

The waved albatross Phoebastria irrorata (Salvin, 1883), listed as a Critically Endangered species (IUCN 2016), breeds exclusively in Ecuador with 9,600 breeding pairs as to 2001 (ACAP 2015) and exhibits an at-sea distribution which extends to northern Peru during both breeding and post-breeding seasons (Anderson et al. 2003). Waved albatrosses breed annually producing a single chick over an 8-month period with chicks leaving the colony between December to April (Tickell 2000). On land, the main threat is habitat transformation and loss linked to native giant tortoises and introduced goats (Anderson \& Cruz 1998). Mosquito attacks of birds on their nests during high temperatures and rainy conditions of ENSO, which cause nest desertion, are also a threat to survival (Anderson \& Fortner 1988). At sea, breeding adults during different parts of the nesting period could visit foraging areas outside protected areas such as the Galápagos Marine Reserve (Anderson et al. 2003). Thus, the main risks for the waved albatross during at-sea foraging trips are incidental mortality in artisanal fisheries, and intentional hunting for food (Awkerman et al. 2006). Ingestion of marine debris is also a threat (Anderson et al. 2008). Terrestrial and marine threats combined accounted for a $19 \%$ population decline of the species during the last 84 years (BirdLife International 2016), thus reaching the critically endangered status in 2007.

Previous geographic distribution records of waved albatrosses indicated occasional visits to tropical waters to the north of Galápagos along the Pacific coast of Colombia and the Gulf of Panama (Murphy 1936). To the south, records of this species include the northern extreme of the Humboldt Current System related to the Peruvian upwelling in the early breeding season (Anderson \& Cruz 1998). Presence of the species in waters south of this range has been generally linked to El Niño Southern Oscillation (ENSO) effects in waters of southern Peru, such as recent records close to the border with Chile (Pizarro-Neyra 2010).

Here, updated information on waved albatross sightings beyond its known southern distributional range in Chilean waters is presented. Information related to the species presence from fishing and tourism activities in the region was also assessed. The potential threat in oceanic waters off Chile is discussed, beyond the known southern distributional limits of this albatross. In addition, we propose the need to increase observation effort through citizen engagement and systematic surveys by trained fishery observer programs.

\section{MATERIALS AND METHODS}

\section{RECORDS OF WAVED ALBATROSS}

Records on the presence of waved albatrosses in the Chilean southeast Pacific were obtained through surveys conducted from the stern vessels. Seabird assemblages were monitored associated with 3 industrial fisheries. The latter encompass the pelagic longline fishery targeting swordfish Xiphias gladius (Linnaeus, 1758) which was monitored over 6 months (July 2008, July-October 2009 and August 2010) including 94 setting operations and $106.4 \mathrm{~h}$ of observation including all aspects of the set and haul. The area covered was between $23-32^{\circ} \mathrm{S}$ and $77-84^{\circ} \mathrm{W}$ (Fig. 1). Another industrial fishery includes the demersal trawl fishery targeting South Pacific hake Merluccius gayi gayi (Guichenot, 1848) and was monitored over 19 months (June 2011-August 2012, March, May, June and August 2013) with an observation effort of $638.7 \mathrm{~h}$ including all operational aspects of the set, trawl and haul. The spatial coverage was between $33-42^{\circ} \mathrm{S}$ and $71-74^{\circ} \mathrm{W}$ (Fig. 1). Finally, the industrial demersal trawl fishery for nylon shrimp Heterocarpus reedi (Bahamonde, 1955) was monitored over 28 months (2011, 2012, and 2013) except for fishery closures in July, August and December (all years combined). Observation effort was 4,160 $\mathrm{h}$ and covered between $28-36^{\circ} \mathrm{S}$ and $71-73^{\circ} \mathrm{W}$ (Fig. 1) during the set, trawl and haul.

Additionally, all records of waved albatross sightings from tourism operations, electronic publications and records on digital databases (<www.avesdechile.cl> and <www.ebird.org>, respectively) were reviewed and compiled. For this, the following keywords were included: 'Phoebastria irrorata', 'waved albatross', 'albatros de Galápagos', and 'Chile'. Another source of past records was in litteris (in litt.) communications directly obtained from local and foreign tourism operators carrying out activities in Chilean waters since the 1980's.

\section{VARIABLES ASSOCIATED WITH RECORDS AND STATISTICAL ANALYSIS}

The following information for all data sources were extracted: (1) date; (2) distance $(\mathrm{km})$ from the Chilean continental coast and the main breeding site (Isla Española, Galápagos Islands); (3) overlap and potential interaction with fishing activities (e.g., 


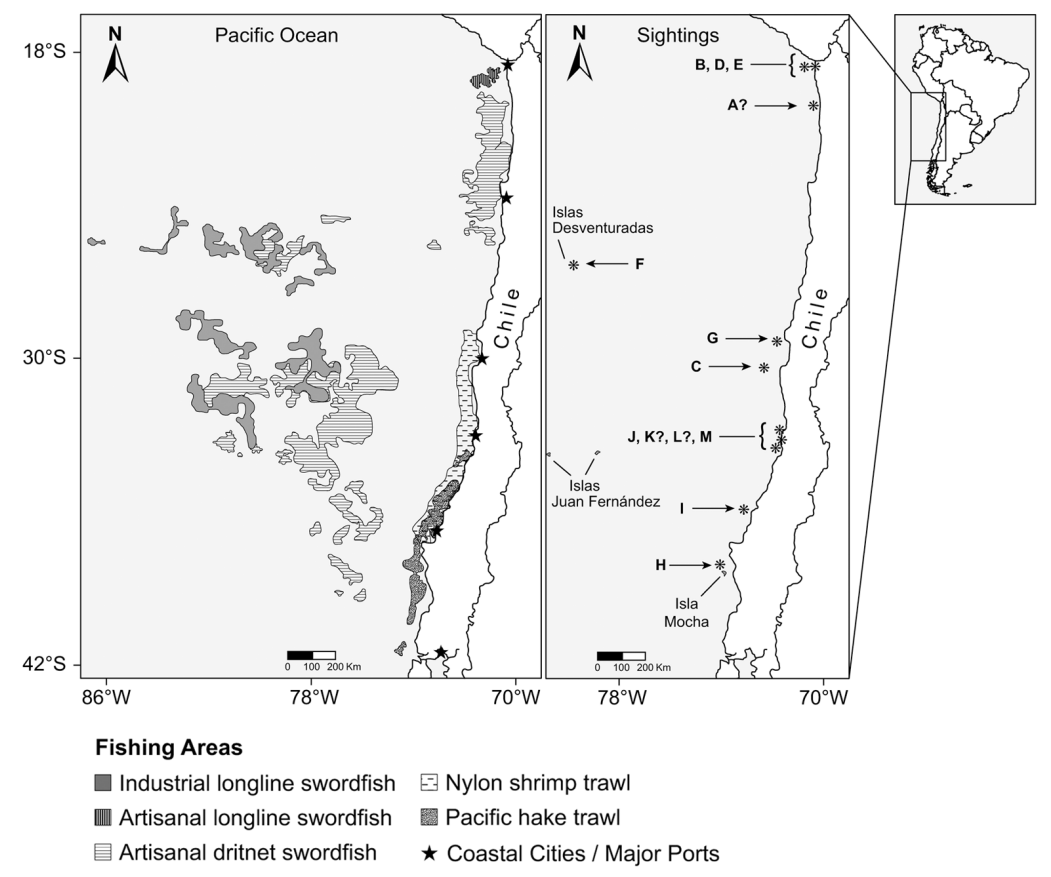

Figure 1. Left: fishing zone distribution between 2011 and 2013 (source: Undersecretariat for Fisheries and Aquaculture - Chilean Government). Artisanal longline and gillnet fishing activities were omitted. Right: waved albatross records in Chilean waters (? = indicates coastal records with no available information on the distance from the coastline). For details of codes, see Table 1 / Izquierda: distribución de zonas de pesca entre los años 2011 y 2013 (fuente: Subsecretaría de Pesca y Acuicultura - Gobierno de Chile). Palangre y enmalle artesanal fueron omitidos. Derecha: Registros de albatros de Galápagos en aguas Chilenas (? = indica registros costeros sin información disponible acerca de la distancia desde la línea de costa). Para detalles de los códigos, ver Tabla 1

feeding on discards/offal, incidental mortality events); and (4) the Southern Oscillation Index (SOI) as a proxy for ENSO events (Jenouvrier et al. 2005).

Monthly standardised SOI values were obtained from the National Climatic Data Center of the National Oceanic and Atmospheric Administration (NOAA, <https:// www.ncdc.noaa.gov>) as a measure of the state of the Southern Oscillation, based on sea-level pressure differences in the western and eastern Pacific. Thus, it was possible to characterise abnormal increases in the ocean temperature which are represented by a permanent negative SOI score and that indicate an El Niño year (<http://www.ncdc.noaa.gov/teleconnections/ enso/indicators/soi/>). This condition was evaluated because the southern oscillation abnormalities influence potential prey (e.g., fish) distribution, which may in turn force seabirds beyond their traditional distributional limits (Jaksic \& Fariña 2010).

Records obtained from different observation platforms (e.g., fisheries and tourism vessels) were tested for homogeneity with Chi-square test for: (1) latitude (north, central and south of
Chile); (2) breeding season (April to December) and (3) SOI (positive, negative). Yates' correction for continuity was applied in cases with two compared categories. All values were expressed as mean $\pm \mathrm{SE}$.

\section{Results}

\section{DiSTRIBUTION OF RECORDS AND ASSOCIATED VARIABLES}

A total of 13 sightings of waved albatrosses were recorded from all sources, including within Chile's Economic Exclusive Zone (EEZ). Of these, 5 sightings of waved albatross (38.5\% of overall records) were associated with industrial fishing activities (Table 1). In oceanic waters around the Islas Desventuradas 2 individuals were registered attending a pelagic longline vessel (Annex 1). Black-browed Thalassarche melanophrys (Temminck, 1828) and Buller's albatrosses Thalassarche bulleri (Rothschild, 1893) comprised 100\% of seabird bycatch for pelagic longline vessels; no waved albatross bycatch was recorded. 
Table 1 Communicated records, electronic reports and original sightings provided by this study for the waved albatross in Chilean waters. Negative SOl (日 Niño), and positive (La Niña). Standardized monthly SOI obtained from Gimate Senvices and Monitoring Division, NOAA (for details see Materials and Methods section). ? =indicates coastal records with no available information on the distance from the coastline / Registros comunicados, informes electrónicos y registros originales proporcionados por este estudio del albatros de Galápagos en aguas Chilenas. SOI negativo (El Niño) y positivo (La Niña). SOI mensualmente estandarizado obtenido desde Climate Services and Monitoring Division, NOAA (para detalles ver sección Materiales y Métodos). ? = indica registros costeros sin información disponible acerca de la distancia desde la línea de costa

\begin{tabular}{|c|c|c|c|c|c|c|c|}
\hline $\begin{array}{l}\text { Legend } \\
\text { in } \\
\text { Figure } 1\end{array}$ & Record date & $\begin{array}{c}\text { No. } \\
\text { individuals }\end{array}$ & $\begin{array}{l}\text { Latitude, site, distance } \\
\quad \text { from coast }(\mathrm{km})\end{array}$ & $\begin{array}{l}\text { Linear distance } \\
\text { from breeding } \\
\text { area }(\mathrm{km})\end{array}$ & SOI & Related to & Reference \\
\hline A & February-April $1980^{\text {(a) }}$ & $1-30$ & $\sim 20^{\circ} \mathrm{S}$, coast of Chile, (?) & $\sim 2,870$ & $-0.2^{(b)}$ & Cargo ship & $\begin{array}{l}\text { Meeth \& Meeth (1983) presented } \\
\text { as appendix in Clark (1986) }\end{array}$ \\
\hline B & November 1997 & 15 & $18^{\circ} \mathrm{S}$, Arica, (30) & $\sim 2,820$ & -1.2 & Tourism & (Hill in litt. 2012) \\
\hline $\mathrm{C}$ & January 1998 & $1^{(\mathrm{c})}$ & $30^{\circ} \mathrm{S}$, Tongoy, $(70)$ & $\sim 3,709$ & -2.7 & Tourism & $\begin{array}{l}\text { (Mackiernan et al. 2001, in litt. } \\
\text { 2012) }\end{array}$ \\
\hline $\mathrm{D}$ & January 1998 & 1 & $18^{\circ} \mathrm{S}$, Arica, $(5,5)$ & $\sim 2,820$ & -2.7 & $\begin{array}{l}\text { Recreational } \\
\text { fishing }\end{array}$ & (Peredo in litt. 2012) \\
\hline $\mathrm{E}$ & March 2004 & 1 & $18^{\circ} \mathrm{S}$, Arica, (31) & $\sim 2,820$ & 0.4 & Tourism & (Knapton \& Herrera in litt. 2012) \\
\hline $\mathrm{F}$ & August 2010 & 2 & $\begin{array}{l}26^{\circ} \mathrm{S} \text {, Islas Desventuradas, } \\
(920)\end{array}$ & $\sim 2,955$ & 1.8 & $\begin{array}{l}\text { Pelagic longline } \\
\text { for } \\
\text { Swordfish }\end{array}$ & (this study) \\
\hline G & February 2011 & 1 & $29^{\circ} \mathrm{S}, \mathrm{W}$ Isla Damas (12) & $\sim 3,632$ & 2.7 & $\begin{array}{l}\text { Demersal trawl for } \\
\text { nylon shrimp }\end{array}$ & (this study) \\
\hline $\mathrm{H}$ & December 2011 & 1 & $\begin{array}{l}38^{\circ} \mathrm{S}, \mathrm{NW} \text { Isla Mocha, } \\
(71)\end{array}$ & $\sim 4,391$ & 2.5 & $\begin{array}{l}\text { Demersal trawl for } \\
\text { South Pacific hake }\end{array}$ & (this study) \\
\hline I & February 2012 & 1 & $35^{\circ} \mathrm{S}$, Pelluhue, $(50)$ & $\sim 4,198$ & 0.5 & $\begin{array}{l}\text { Demersal trawl for } \\
\text { nylon shrimp }\end{array}$ & (this study) \\
\hline $\mathrm{J}$ & March 2012 & 1 & $\begin{array}{l}33^{\circ} \mathrm{S} \text {, Punta Curaumilla- } \\
\text { Valparaíso, (15) }\end{array}$ & $\sim 3,977$ & 0.7 & Tourism & (Reyes \& Romo 2012) $^{(\mathrm{d})}$ \\
\hline K & November 2012 & 1 & $\sim 32^{\circ} \mathrm{S}$, Quintero, (?) & $\sim 3,956$ & 0.3 & Tourism & (Tapia 2012) $^{\text {(d) }}$ \\
\hline $\mathrm{L}$ & February 2013 & 1 & $\sim 32^{\circ} \mathrm{S}$, Quintero, (?) & $\sim 3,956$ & -0.2 & Tourism & $\left(\right.$ Reyes-A. 2013) ${ }^{(\mathrm{d})}$ \\
\hline M & February 2013 & 1 & $33^{\circ} \mathrm{S}$, Quintay, (18) & $\sim 3,989$ & -0.2 & $\begin{array}{l}\text { Demersal trawl for } \\
\text { nylon shrimp }\end{array}$ & (this study) \\
\hline
\end{tabular}

\footnotetext{
(a) No specification of date recorded

(b) Mean SOI for the period from February-April 1980

(c) Previous individuals observed in Chilean waters were all north of this record

(d) Record cited at $<$ http://www.avesdechile.cl
} 
One adult waved albatross was observed feeding on discards from a demersal trawl vessel fishing for hake near Isla Mocha in south-central Chile (Annex 2). In this fishery, black-browed and Salvin's Thalassarche salvini (Rothschild, 1893) albatrosses were recorded, representing $57.9 \%$ of total mortality; there was no bycatch of waved albatross.

During monitoring of nylon shrimp trawls in north and central Chile, 3 waved albatrosses were recorded consuming discards, such as flatfish and grenadiers together with other albatrosses, pelicans and gulls between 29 and $35^{\circ} \mathrm{S}$ (Fig. 2). No negative seabird interactions or bycatch was identified in this fishery.

Additional records (53.8\% of all records) were obtained from 7 pelagic birdwatching and recreational fishing trips, mainly concentrated in northern and central Chile (Arica $\sim 18^{\circ} \mathrm{S}$ and
Valparaíso $\sim 33^{\circ} \mathrm{S}$, respectively), associated with the continental shelf of Chile. Also, one waved albatross was observed during birdwatching trips from a cargo ship in the early 1980's (Table $1)$.

In Chilean waters, the waved albatross was more frequently recorded off central Chile $\left(\chi_{(2)}^{2}=5.70, P=0.02\right)$. The boundary of the southern distributional range of this albatross is $c a$., 4,391 $\mathrm{km}$ from the Galápagos breeding grounds, which represents a mean range in Chilean waters of 3,545 $\pm 166 \mathrm{~km}(n=13)$. The longitudinal distribution of this species was recorded between the coastal areas of the continental shelf and the Islas Desventuradas, $920 \mathrm{~km}$ to the west of the Chilean coast (Fig. $1)$, indicating a mean distance of $122 \pm 89 \mathrm{~km}(n=10$; Table 1) from land.
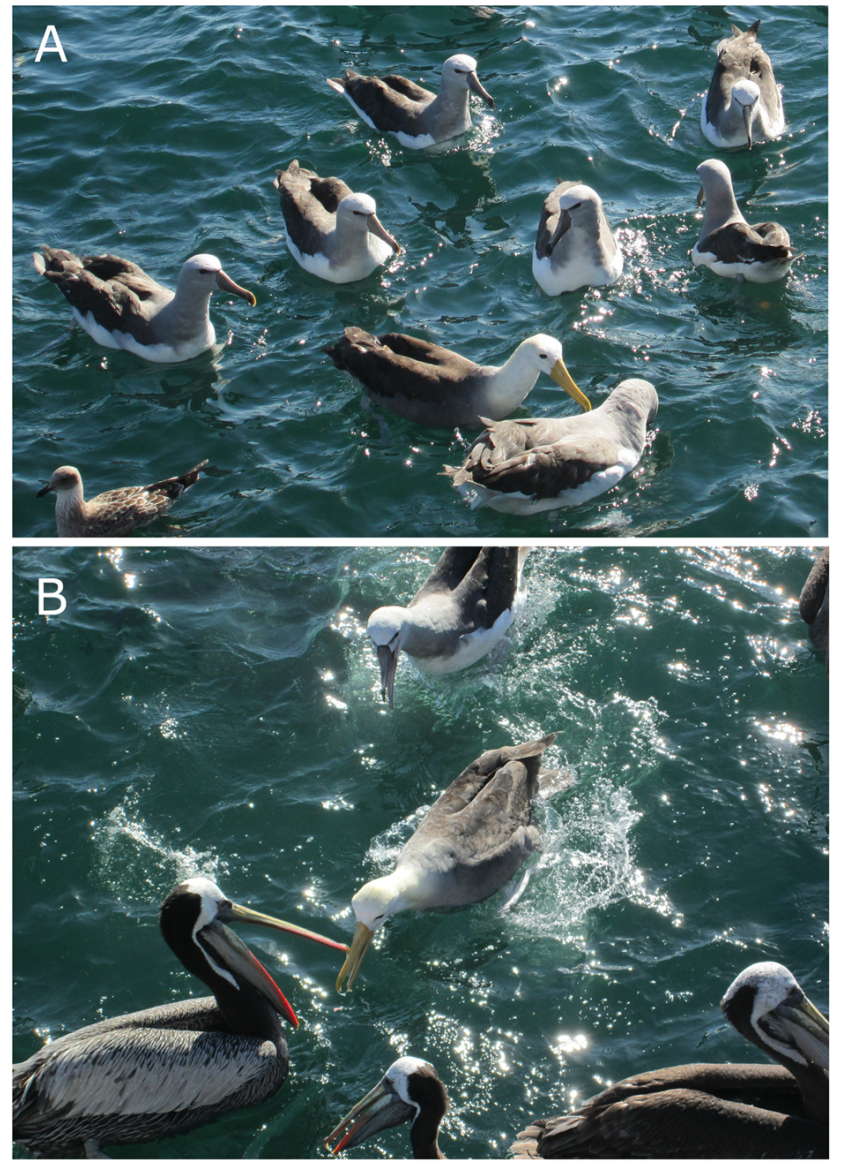

Figure 2. Waved albatross attending discards during industrial trawling for crustaceans off the central coast of Chile (February 2013). A) feeding on discards with visiting Salvin's albatross Thalassarche salvini. B) feeding with Peruvian pelican Pelecanus thagus an endemic species from the Humboldt Current System / Albatros de Galápagos atendiendo descartes durante arrastre industrial dirigido a crustáceos en la costa de Chile central (febrero 2013). A) alimentándose de descartes con el visitante albatros de Salvin Thalassarche salvini. B) alimentándose junto con pelícanos Pelecanus thagus, especies endémicas del Sistema de Corriente de Humboldt 
Of the overall combined records, only $23.1 \%$ occurred during the breeding season $\left(\chi^{2}=2.76, P=0.0001\right)$. Finally, since the 1980 's, $53.8 \%$ of the records of this species have occurred during periods of positive SOI conditions when compared to records with negative SOI values (ENSO conditions).

\section{Discussion}

Most records of waved albatross in Chilean waters were obtained off central Chile, a region related to the Humboldt Current System where the combined sources of observations between tourism operations and fisheries represented $61.5 \%$ of the identified sightings. Data indicate that the maximum distance recorded was over $4,000 \mathrm{~km}$ south from the Galápagos. This represents 3.39 times the maximum distance described for tracked breeding adults for this species during feeding trips in the chick-rearing period (Fernández et al. 2001) off the Peruvian coast. The longitudinal distribution of tracked birds included shallow coastal areas of the continental shelf close to the Galápagos during feeding trips (Awkerman et al. 2005), but also remote areas in oceanic islands (Fig. 1) off the Southeast Pacific during the breeding period as recorded in this study. The waved albatross breeds annually between April and December with adults departing during January and February to spend the non-breeding period along the Peruvian shelf (Anderson \& Cruz 1998). As 76.9\% of the sightings for Chile occurred during the non-breeding period for the species, it may suggest long distance incursions by some individuals. This is contrasting with strong distributional patterns related to certain areas (Anderson et al. 1998, Awkerman et al. 2005) described during different phases of the breeding period.

The presence of waved albatrosses further south from its traditional distribution is mainly attributed to abnormally high ocean temperatures, such as strong ENSO events (Hughes 1985) in southern Peru. An increased number of sightings were linked to strong ENSO events by consecutive observation periods in northern Chile during 1998 (Mackiernan et al. 2001). By contrast, $53.8 \%$ of records during this study were compiled during periods of cold water (i.e., positive SOI; Table 1). Although sample size is small and the compilation is influenced by sampling effort among periods and sources of sightings, results may also suggest that southern distribution of the waved albatross could be independent of warmer water temperatures in this section of the Pacific.

Anderson et al. (1998) previously determined that during incubation, waved albatrosses visit an area of high productivity related to upwellings off the Peruvian coast $1,200 \mathrm{~km}$ from the Galápagos Islands. On a global scale, the Humboldt Current is one of only two Large Marine Ecosystems (together with the California Current) which have maintained persistent cold waters for over 25 years (Belkin 2009) and is recognized as a zone of high productivity which can attract waved albatross during different SOI conditions.

Oceanic fisheries, such as pelagic longline, support high trophic level consumers, primarily through offal from target swordfish, blue shark Prionace glauca (Linnaeus, 1758) and shortfin mako shark Isurus oxyrinchus (Rafinesque, 1809), together with discarded fish and squid bait. During the late 1980's one potential threat with no direct bycatch records described for the waved albatross was the presence of Japanese tuna longline fishing vessels in tropical waters (Anderson et al. 1998). This threat should be extended to Chilean waters where pelagic longline is also present.

Demersal trawl vessels operate along the continental slope and are a major source of discards, which attract seabirds. The South Pacific hake trawl fishery discards crustaceans, flatfish, and offal. The mortality of at least 7 seabird species has been recorded in this fishery, through net entanglement or collision with trawl and netsonde cables (BirdLife International 2013). The crustacean trawl fishery that operates between $28^{\circ} \mathrm{S}$ and $37^{\circ} \mathrm{S}$ targets nylon shrimp, red squat lobster Pleuroncodes monodon (H. Milne Edwards, 1837), and yellow squat lobster Cervimunida johni (Porter, 1903) and discards non-target demersal species. While no seabird bycatch has been recorded for this fishery (ATF-Chile 2010), waved albatross attend vessels to feed on discards and therefore may interact with fishing gear.

This study does not report mortality of waved albatrosses associated with industrial fishing vessels, but extends the known range of the species further south and its potential threats related to fisheries, as recorded on other seabird species in Chile (Cabezas et al. 2009, 2012). For this reason, further monitoring of the main fisheries discussed is recommended.

Beyond the industrial fishing fleets, artisanal fisheries may also represent a threat to waved albatrosses. The bycatch of waved albatrosses in Peruvian artisanal fisheries is considered an important source of mortality (Jiménez-Uzcátegui et al. 2006). In Chile, small-scale artisanal longline and gillnet fishing are widely distributed along the coast (Fig. 1) with $~ 12,600$ active vessels (García 2014). There are no dedicated seabird observers monitoring small-scale fisheries in Chile, although bycatch of at least seven diving seabird species has been confirmed in artisanal longline and gillnet fisheries (Suazo et al. 2014). In the 1980's pelagic drift nets were associated with marine turtle bycatch (Frazier \& Brito 1990). This fishing gear is deployed between central and northern Chile (Fig. 1) but is 
another example of unsurvey small-scale fleets with potential to impact seabirds.

The waved albatross is also under threat from intentional take during fishing as described in neighbouring Peruvian waters (Alfaro-Shigueto et al. 2016). This source of mortality has been demonstrated through ring recoveries from albatrosses and petrels in central and south-central Chile (Moore \& Battam 2000), and overlapped with the southernmost record for waved albatross in this study. This practice was also described in artisanal fisheries around the Chonos Archipelago $\left(45^{\circ} \mathrm{S}\right)$ where seabirds such as penguins, gulls, and fulmars were intentionally caught for use as bait in traps for crab and demersal longline (Suazo et al. 2013).

Records of waved albatrosses in Chilean waters span over 3 decades (since the early 1980's; Table 1) and are associated with a progressive increase of at-sea observation effort from ornithological expeditions and pelagic birdwatching along the Chilean coast. Birdwatching began in Chile in the late 1990's and early 2000's (Simeone in litt. 2014). Although by 2013 no official records of dedicated pelagic birdwatching tours were found. The search uncovered 94 registered marine excursions companies by local tourism authorities during 2013. Of these, only 16 operated in northern and central Chile and four were linked to oceanic islands such as Easter Island (SERNATUR in litt. 2013). Existing birdwatching tours included trips conducted up to $30 \mathrm{~km}$ off the coast representing a total effort of around 26 pelagic excursions (182 h) per year for a single company (Romo in litt. 2013).

Recreational trips overlapped with $92.3 \%$ of waved albatross sightings identified during this study. This provides an attractive opportunity for collaboration between tourism operators as citizen scientists and researchers (Dickinson et al. 2012) into the ecology and conservation of pelagic species. Thus, participatory online databases such as eBird constitute an important reinforcement of individual efforts during the collection of information by citizens (Sullivan et al. 2014), supported by experienced observers/citizen scientists from tourism trips. Definitely, this will increase the value of collective information gathered by tourism operations, especially in regions where researchers are scarce (Sekercioglu 2002), as is the case of the extended coastal and oceanic Chilean waters. Nevertheless, the use of bait to attract seabirds during these recreational trips must also be assessed because an ethical responsibility during pelagic birdwatching trips is also needed.

The role of fisheries' observers and tourism activities could therefore be important for the improvement of systematic data collection as highlighted by Jiménez-Uzcátegui et al. (2006). The information obtained in this study along with a growing effort to monitor the occurrence, distribution and abundance of waved albatrosses and other seabird species in Chile could be relevant in reinforcing local conservation strategies. Amongst these, the National Plan of Action for Reducing Bycatch of Seabirds in longline fisheries locally called Plan de Acción Nacional-Aves Marinas; PAN-AM/Chile (SUBPESCA 2007) aims to expand monitoring coverage beyond the industrial longline fishery, which is currently the only observed fleet. Training workshops and practical excursions support the extension of data collection to new fisheries such as trawl, purse seine and gillnet fisheries (Suazo et al. 2014).

The information in this study may also contribute to regional initiatives such as the Agreement on the Conservation of Albatrosses and Petrels (ACAP) species action plan for the waved albatross (ACAP 2008).

In a global assessment, Croxall et al. (2012) recognized Chile as one of the most important countries in the Pacific in terms of the number of endemic seabirds and visiting species of conservation concern. Official, scientific and citizen efforts serve as an opportunity to integrate information from this important and extensive area so as to improve the conservation status of cross-border species like the waved albatross via a Southeast Pacific monitoring network for endangered species. Examples coming from the Northern Hemisphere of regional plans of action focused on shared species such as the pink-footed shearwater in Canada, USA and Mexico (CEC 2005) can be applied in other regional contexts for the Pacific, such as the South Pacific Regional Fisheries Management Organization (SPRFMO) and the Inter-American Tropical Tuna Commission (IATTC). It is shown how data from fishery observers and information derived from tourism can be helpful, when processed and communicated to feed into shared action plans on key species.

\section{ACKNOWLEDGMENTS}

Our gratitude goes to Barbara Knapton, Ronny Peredo, Gail Mackiernan, Armas Hill and all tourism operators in Chilean waters for openly sharing their records on waved albatrosses from northern and central Chile. To Franco Romo (Pelagic Adventure) for sharing his knowledge of pelagic birdwatching effort in the Humboldt Current. We thank fishing crews and observers for their support during at-sea work, especially Jorge Ruiz, Olliver Riegel (Isla Picton) and Rodrigo Galleguillos (IFOP). Many thanks to Steve Copsey, Stephen Chapman, Joanna Alfaro-Shigueto, Travis Rosenberry, Alejandro Simeone, Servicio Nacional de Turismo (SERNATUR-Chile) and The National Library of Australia for providing key information and literature. Finally, we thank Graham Robertson, John Cooper, John P. Croxall, Stephanie Winnard, and four anonymous 
reviewers for all their support and comments during the preparation of this manuscript. Cristián G. Suazo dedicates this work to the memory of Professor Roberto P. Schlatter.

\section{LITERATURE CITED}

ACAP. 2008. Draft action plan for waved albatross Phoebastria irrorata. Agreement for the Conservation of Albatrosses and Petrels. Hobart, Tasmania. 〈http://www.acap.aq>

ACAP. 2015. Species factsheet: Waved albatross Phoebastria irrorata. Agreement for the Conservation of Albatrosses and Petrels. Hobart, Tasmania. 〈http://www.acap.aq>

Alfaro-Shigueto J, JC Mangel, K Valenzuela \& M AriasSchreiber. 2016. The intentional harvest of waved albatrosses Phoebastria irrorata by small-scale offshore fishermen from Salaverry port, Peru. Pan-American Journal of Aquatic Sciences 11: 70-77.

Anderson DJ \& S Fortner. 1988. Waved albatross egg neglect and associated mosquito ectoparasitism. Condor 90: 727-729.

Anderson DJ \& F Cruz. 1998. Biology and management of the waved albatross at the Galápagos Islands. In: Robertson G \& R Gales (eds). Albatross: Biology and conservation, pp. 105-109. Surrey Beatty \& Sons, New South Wales.

Anderson DJ, AJ Schwandt \& HD Douglas. 1998. Foraging ranges of waved albatrosses in the eastern Tropical Pacific Ocean. In: Robertson G \& R Gales (eds). Albatross: Biology and conservation, pp. 180-185. Surrey Beatty \& Sons, New South Wales.

Anderson DJ, KP Huyvaert, DR Wood, CL Gillikin, BJ Frost \& H Mouritsen. 2003. At-sea distribution of waved albatrosses and the Galápagos Marine Reserve. Biological Conservation 110: 367-373.

Anderson DJ, KP Huyvaert, JA Awkerman, CB Proaño, WB Milstead, G Jiménez-Uzcátegui, S Cruz \& JK Grace. 2008. Population status of the Critically Endangered waved albatross Phoebastria irrorata, 1999 to 2007. Endangered Species Research 5: 185-192.

ATF-Chile. 2010. Reporte de actividades (Enero 2009 - Enero 2010). Report Albatross Task Force-Chile, BirdLife International, Chile.

Awkerman JA, A Fukuda, H Higuchi \& DJ Anderson. 2005. Foraging activity and submesoscale habitat use of waved albatrosses Phoebastria irrorata during chickbrooding period. Marine Ecology Progress Series 291: 289300 .

Awkerman JA, KP Huyvaert, J Mangel, J Alfaro-Shigueto \& DJ Anderson. 2006. Incidental and intentional catch threatens Galápagos waved albatross. Biological Conservation 133: 483-489.

Belkin IM. 2009. Rapid warming of Large Marine Ecosystems. Progress in Oceanography 81: 207-213.
BirdLife International. 2013. Seabird mortality in the Chilean demersal hake trawl fishery and the effect of bird-scaring lines as a mitigation measure. Seabird Bycatch Working Group 5, Doc 39. Agreement for the Conservation of Albatrosses and Petrels. La Rochelle. <https://www.acap.aq/en/workinggroups/seabird-bycatch-working-group/seabird-bycatch-wgmeeting-5/2034-sbwg5-doc-39-seabird-mortality-in-thechilean-demersal-hake-trawl-fishery-and-the-effect-of-birdscaring-lines-as-a-mitigation-measure/file>

BirdLife International. 2016. Phoebastria irrorata. The IUCN Red List of Threatened Species 2016. <http:// dx.doi.org/10.2305/IUCN.UK.2016-3.RLTS.T2269832 0A93678476.en>

Cabezas LA, CA Moreno \& J Arata. 2009. New records of Salvin's albatross (Thalassarche salvini) from fishing boats off southern Chile. Polar Biology 32: 947-951.

Cabezas LA, J Ruiz, O Yates \& M Bernal. 2012. The black petrel (Procellaria parkinsoni) in pelagic waters off northern Chile: a southern extension to the known distribution and interactions with the pelagic longline fishery. New Zealand Journal of Marine and Freshwater Research 46: 537-544.

CEC. 2005. North American conservation plan for the Pinkfooted shearwater. Commission for Environmental Cooperation, Montreal. <http://www2.cec.org/nampan/sites/ default/files/pink-footed-shearwater.pdf >

Clark GS. 1986. Seabirds observed in the Pacific southern ocean during autumn. Australasian Seabird Group Newsletter 23: $1-15$.

Croxall JP, SHM Butchart, B Lascelles, AJ Stattersfield, B Sullivan, A Symes \& P Taylor. 2012. Seabird conservation status, threats and priority actions: a global assessment. Bird Conservation International 22: 1-34.

Dickinson JL, J Shirk, D Bonter, R Bonney, RL Crain, J Martin, T Phillips \& K Purcell. 2012. The current state of citizen science as a tool for ecological research and public engagement. Frontiers in Ecology and the Environment 10: 291-297.

Fernández P, DJ Anderson, PR Sievert \& KP Huyvaert. 2001. Foraging destinations of three low-latitude albatross (Phoebastria) species. Journal of Zoology 254: 391-404.

Frazier JG \& JL Brito. 1990. Incidental capture of marine turtles by the swordfish fishery at San Antonio, Chile. Marine Turtle Newsletter 49: 8-13.

García M. 2014. Overview of the fisheries and seabird bycatch in Chile. 2nd Meeting of the Scientific Committee, Honolulu, Hawaii, USA, 1-7 October 2014, SC-02-19_rev1. South Pacific Regional Fisheries Management Organization, Honolulu. <http://www.sprfmo.int/assets/Meetings/Meetings2013-plus/SC-Meetings/2nd-SC-Meeting-2014/Papers/SC02-19-rev1-Overview-of-the-fisheries-and-seabird-bycatchin-Chile.pdf>

Hughes R. 1985. Notes on the effects of El Niño on the seabirds of the Mollendo district, southwest Perú in 1983. Ibis 127: 385-388. 
IUCN. 2016. IUCN Red List of Threatened Species. Version 2016-3. Gland, Switzerland. <http://www.iucnredlist.org>

Jaksic FM \& JM Fariña. 2010. El Niño and the birds: a resource-based interpretation of climatic forcing in the southeastern Pacific. Anales del Instituto de la Patagonia 38: $121-140$

Jenouvrier S, H Weimerskirch, C Barbraud, Y-H Park \& B Cazelles. 2005. Evidence of a shift in the cyclicity of Antarctic seabird dynamics linked to climate. Proceedings of the Royal Society B 272: 887-895.

Jiménez-Uzcátegui G, J Mangel, J Alfaro-Shigueto \& D Anderson. 2006. Fishery bycatch of the waved albatross Phoebastria irrorata, a need for implementation of agreements. Galapagos Research 64: 7-9.

Mackiernan G, P Londsdale, N Shany, B Cooper \& P Ginsburg. 2001. Observations of seabirds in Peruvian and Chilean waters during the 1998 El Niño. Cotinga 15: 85-94.

Meeth P \& K Meeth. 1983. Seabird observations from six Pacific Ocean crossings. Sea Swallow 32: 58-65.

Moore PJ \& H Battam. 2000. Procellariiformes killed by fishers in Chile to obtain bands. Notornis 47: 168-169.

Murphy RC. 1936. Oceanic birds of South America. Vol. 1: 1640. The American Museum of Natural History, The MacMillan Company, New York.

Pizarro-Neyra J. 2010. Two rare albatrosses in southern Peru. Cotinga 32: 110 .

Robertson G, C Moreno, JA Arata, SG Candy, K Lawton, J Valencia, B Wienecke, R Kirkwood, P Taylor \& CG Suazo. 2014. Black-browed albatross numbers in Chile increase in response to reduced mortality in fisheries. Biological Conservation 169: 319-333.

Robertson G, B Wienecke, CG Suazo, K Lawton, JA Arata \& C Moreno. 2017. Continued increase in the number of black-browed albatrosses (Thalassarche melanophris) at Diego Ramírez, Chile. Polar Biology 40: 1035-1042.
Sekercioglu CH. 2002. Impacts of birdwatching on human and avian communities. Environmental Conservation 29: 282289.

Suazo CG, RP Schlatter, AM Arriagada, LA Cabezas \& J Ojeda. 2013. Fishermen's perceptions of interactions between seabirds and artisanal fisheries in the Chonos archipelago, Chilean Patagonia. Oryx 47: 184-189.

Suazo CG, LA Cabezas, CA Moreno, JA Arata, G LunaJorquera, A Simeone, L Adasme, J Azócar, M García, O Yates \& G Robertson. 2014. Seabird bycatch in Chile: a synthesis of its impacts and a review of strategies to contribute to the reduction of a global phenomenon. Pacific Seabirds 41: 1-12.

SUBPESCA. 2007. Plan de Acción Nacional para reducir las capturas incidentales de aves en las pesquerías de palangre (PAN-AM/CHILE). Subsecretaría de Pesca y Acuicultura, Valparaíso, Chile. <http://www.subpesca.cl/institucional/602/ articles-79723_recurso_1.pdf >

Sullivan BL, JL Aycrigg, JH Barry, RE Bonney, N Bruns, CB Cooper, T Damoulas, AA Dhondt, T Dietterich, A Farnsworth, D Fink, JW Fitzpatrick, T Fredericks, J Gerbracht, C Gomes, WM Hochachka, MJ Iliff, C Lagoze, FA La Sorte, M Merrifield, W Morris, TB Phillips, M Reynolds, AD Rodewald, KV Rosenberg, NM Trautmann, A Wiggins, DW Winkler, W-K Wong, CL Wood, J Yu \& S Kelling. 2014. The eBird enterprise: An integrated approach to development and application of citizen science. Biological Conservation 169: 31-40.

Tickell WLN. 2000. Albatrosses, 448 pp. Yale University Press, New Haven. 

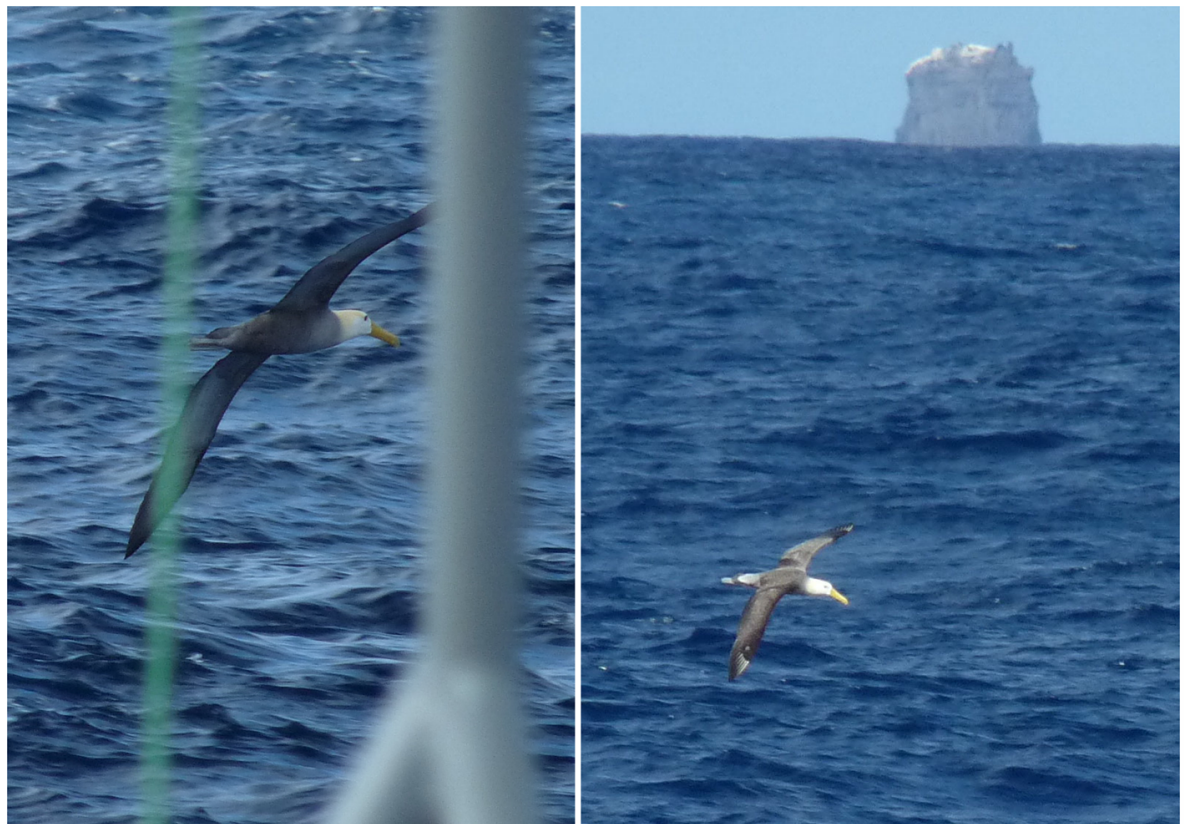

Annex 1. An adult waved albatross recorded following a swordfish longline vessel in August 2010 near to Islas Desventuradas, Chile / Adulto de albatros de Galápagos registrado siguiendo un barco de pesca de palangre pelágico para pez espada en agosto 2010, cerca de Islas Desventuradas, Chile Photos by / fotos de: Luis A. Cabezas
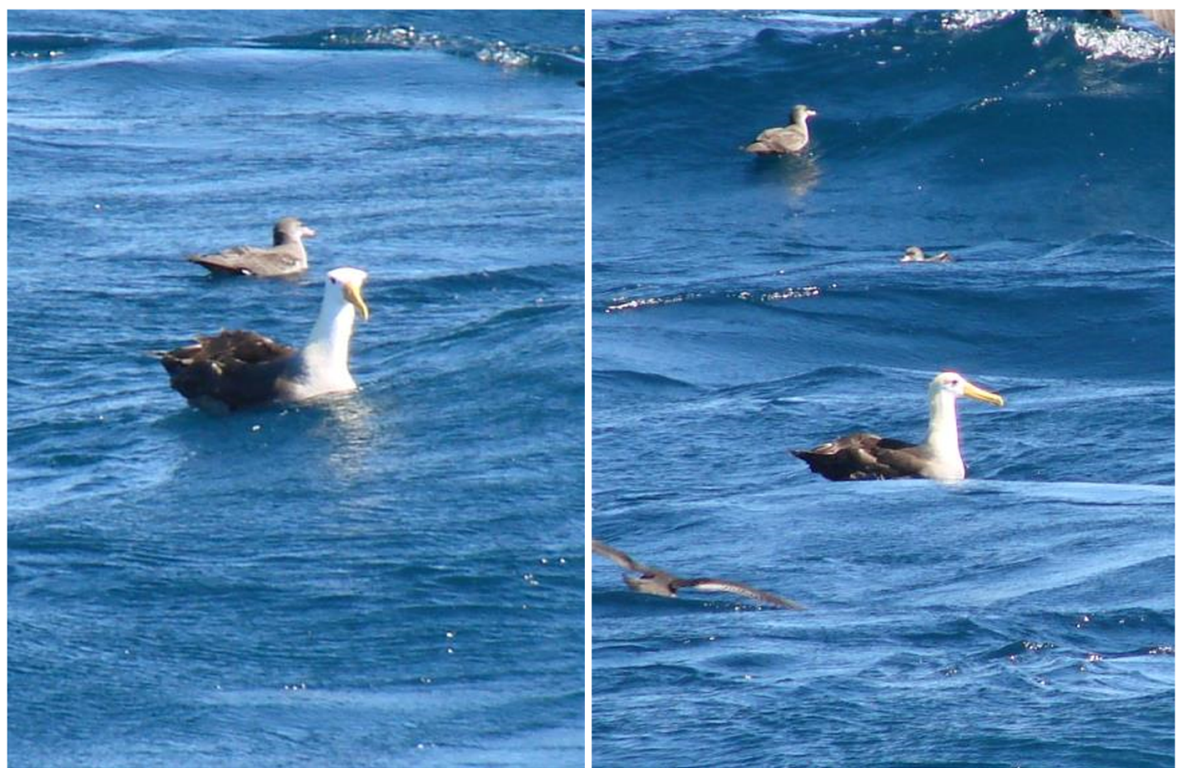

Annex 2. An adult waved albatross associated with Pink-footed shearwaters attending a trawl vessel for South Pacific hake during December 2011, north of the Isla Mocha, Chile / Adulto de albatros de Galápagos asociado con fardelas blancas asistiendo en un barco de arrastre para Merluza común durante diciembre 2011, al norte de Isla Mocha, Chile. Photos by / fotos de: Cristián G. Suazo 